PROFESI (Profesional Islam)

Media Publikasi Penelitian; 2017; Volume 15; No 1.

Website: ejournal@stikespku.ac.id

\title{
Pengaruh TFC Terhadap Perubahan Status Gizi (BB/U dan TB/U) Balita Gizi Kurang Di Kabupaten Sukoharjo
}

\author{
Desi Nurfatimah $^{1^{*}}$, Luluk Ria Rakhma ${ }^{2}$ \\ ${ }^{1}$ Prodi Ilmu Gizi/Fakultas Ilmu Kesehatan, Universitas Muhammadiyah Surakarta \\ ${ }^{2}$ Prodi Ilmu Gizi/Fakultas Ilmu Kesehatan, Universitas Muhammadiyah Surakarta \\ *Email: desinfatimah.dn@gmail.com
}

Kata Kunci
Balita gizi kurang,
Status Gizi,
Therapeutic Feeding
Centre (TFC)

\section{Abstrak}

Kasus gizi kurang di Sukoharjo mencapai 2476 balita (4,98\%) dan gizi buruk sebanyak 286 balita (0,58\%). Penelitian ini bertujuan untuk mengetahui pengaruh TFC terhadap perubahan status gizi (BB/U dan TB/U) pada balita gizi kurang di Kabupaten Sukoharjo. Jenis penelitian ini adalah observasional dengan pendekatan cross sectional. Jumlah subjek penelitan sebanyak 35 balita (TFC) dan 30 balita (NONTFC). Teknik pengambilan sampel adalah Total Sampling (TFC) dan Simple Random Sampling (NONTFC). Uji kenormalan data menggunakan Uji Kolmogorov Smirnov. Hasil uji kenormalan data adalah normal, sehingga menguji pengaruh menggunakan Uji Simple T-Test Independent. Penelitian menunjukkan nilai rata-rata perubahan status gizi $B B / U$ dan $T B / U$ balita yang mengikuti TFC adalah $0,33 \pm 0,45$ dan $-0,06 \pm 0,34$. Nilai rata-rata perubahan status gizi $B B / U$ dan

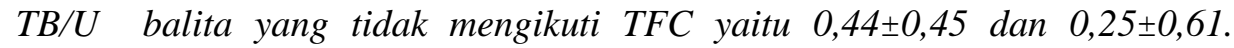
Berdasarkan hasil uji pengaruh TFC terhadap perubahan status gizi BB/U dan $T B / U$ pada balita gizi kurang mendapatkan nilai $p=0,34$ dan $p=0,26$. Tidak ada pengaruh TFC terhadap perubahan status gizi (BB/U dan $T B / U)$ pada balita gizi kurang di Kabupaten Sukoharjo.

\section{Effect Of TFC To The Changes In Nutritional Status (W/A And H/A) In Malnutrition Toddlers In The Sukoharjo District}

\section{Keywords}

Malnutrition of toddlers, nutritional status, Therapeutic Feeding Center (TFC)

\begin{abstract}
Cases of malnutrition in Sukoharjo reached 2476 toddlers (4.98\%) and severe malnutrition as many as 286 toddlers (0.58\%). This study aimed to determine the effect of TFC to changes in nutritional status (W/A and H/A) in malnutrition toddlers in Sukoharjo. This was an observational study with cross sectional approach. The number of research subjects were 35 toddlers (TFC) and 30 toddlers (NONTFC). The sampling techniqes used total sampling (TFC) and Simple Random Sampling (NONTFC) methods. The analyze of data normality used Kolmogorov Smirnov test. The result of normality data test was normal, so testing the effect used Simple Independent T-Test. The study showed that the average value of changes in nutritional status W/A and H/A in toddlers who received $T F C$ were $0.33 \pm 0.45$ and $-0,06 \pm 0,34$ respectively. The average value of changes in the nutritional status of W/A and H/A in toddlers who did not received TFC were 0,44 $\pm 0,45$ and 0,25 $\pm 0,61$ respectively. Based on the test, the effect of TFC to changes in the nutritional status of W/A and H/A on malnutrition toddlers got the value of $p=0,34$ and $p=0,26$. There was no effect of TFC to changes in nutritional status (W/A and H/A) on malnutrition toddlers in Sukoharjo.
\end{abstract}




\section{PENDAHULUAN}

Indonesia mempunyai masalah kese-hatan yang perlu diperhatikan permasalahn gizi ganda yakni gizi kurang dan gizi lebih. Gizi lebih bisa overweight dan obesitas. Negara berkembang seperti Asia merupakan negara-negara yang banyak terjadi masalah gizi kurang (Muller dan Krawinkel, 2005). Gizi kurang dapat dibedakan menjadi buruk dan stunting. Gizi buruk merupakan salah satu faktor penyumbang tingginya angka kesakitan dan kematian yang terjadi pada balita (Hickson, 2006).

Menurut Rosha dkk (2014) dalam penelitiannya tentang gizi kurang pada balita disebabkan oleh beberapa faktor diantaranya penyebab langsung yaitu asupan makan yang tidak cukup dan kejadian penyakit infeksi. Dampak dari gizi kurang yang kompleks yaitu anak dapat mengalami gangguan pada perkembangan mental, sosial, kognitif dan pertumbuhan yaitu berupa ketidakseimbangan fungsi organ, fungsi kekebalan tubuh yang rendah sehingga menyebabkan kerentanan terhadap penyakit-penyakit seperti infeksi saluran pernafasan, diare dan demam (Supartini, 2004; Feinstorm., et al, 2005). Dampak yang lebih parah adalah akan terjadi kematian yang lebih dini (Suhardjo, 2003).

Status gizi salah satu aspek yang digunakan untuk memantau pertumbuhan dan perkembangan anak bisa juga sebagai cerminan kesehatan bagi siapapun. Penilaian status gizi balita dilakukan di Posyandu dengan menggunakan indeks antropometri. Indeks Berat Badan Menurut Umur (BB/U), Tinggi Badan Menurut Umur (TB/U). Pengukuran antropometri dengan indeks berat badan menurut umur $(\mathrm{BB} / \mathrm{U})$ mencerminkan status gizi saat ini (Current Nutrition), yang artinya sangat labil mudah mengalami kenaikan atau penurunan. Tinggi badan menurut umur $(\mathrm{TB} / \mathrm{U})$ relatif kurang sensitif terhadap masalah kekurangan gizi dalam waktu yang pendek sehingga $\mathrm{TB} / \mathrm{U}$ meng-gambarkan status gizi pada masa lampau (Supariasa., dkk, 2012).

Pemerintah sudah melakukan usaha dalam penanganan kasus gizi kurang maupun gizi buruk diantaranya adalah progam Therapeutic Feeding Centre (TFC). TFC adalah salah satu upaya pemerintah untuk pemulihan anak balita dengan permasalahan gizi, baik gizi kurang maupun gizi buruk. Fungsi dari TFC adalah sebagai wadah penanggulangan gizi buruk maupun gizi kurang balita dengan cara melakukan perawatan atau pengobatan secara intensif dengan melibatkan ibu atau keluarga dalam perawatan balita. Jenis pelayanan yang ada di TFC diantaranya penimbangan BB, pelayanan konseling gizi, PMT, penyuluhan, konsultasi serta rujukan gizi dan lain-lain. (Kemenkes, 2011).

Data Riset Kesehatan Dasar (Riskesdas) di Indonesia tahun 2013 menyatakan bahwa prevalensi balita gizi kurang dan buruk mencapai $19,6 \%$, provinsi Jawa Tengah sebesar $12 \%$ dan di Kabupaten Sukoharjo mencapai 10,8\% (Riskesdas, 2013). Data Dinas Kesehatan di Kabupaten Sukoharjo sepanjang tahun 2015 pada prevalensi balita yang mengalami gizi kurang dengan indeks BB/U mencapai 2209 balita (4,67\%) (Dinkes Sukoharjo, 2015). Angka tersebut naik di tahun 2016 dari bulan Januari sampai Februari sebesar 2476 balita yang mengalami gizi kurang $(4,98 \%)$ (Dinkes Sukoharjo, 2016).

Kabupaten Sukoharjo merupakan salah satu Kabupaten di Provinsi Jawa Tengah yang pemerintahannya sudah menerapkan progam TFC untuk menangani kasus gizi kurang maupun buruk balita. Progam yang sudah berjalan sejak tahun 2013, telah mengalami perkembangan yang pesat. Berdasarkan survey yang dilakukan Kabupaten Sukoharjo progam TFC yang berlangsung selama satu periode pada tahun 2016 yaitu di Puskesmas Gatak, Sukoharjo dan Weru. Jumlah total balita yang mengikuti TFC sebanyak 50 balita gizi kurang dan buruk

\section{METODE PENELITIAN}

Desain penelitian ini merupakan penelitian obsevasional dengan pendekatan cross sectional yang dilaksanakan di Kabupaten Sukoharjo. Responden dalam penelitian ini adalah balita yang megalami gizi kurang dan buruk di Kabupaten Sukoharjo. Penelitian berlangsung selama 90 hari (12 minggu) dengan pengambilan data sebanyak $4 x$ pada minggu 1 , minggu ke-4, minggu ke-8 dan minggu ke-12. Jumlah balita yang mengikuti TFC sebanyak 50 tetapi yang termasuk dalam kriteria inklusi hanya 35 balita dan yang 15 droup out. Satu menderita sakit, 2 memiliki status gizi normal, 3 merupakan pergantian balita yang pernah hadir dan 9 tidak hadir dalam pengambilan data. Balita yang tidak mengikuti TFC berjumlah 30 balita. 
Teknik pengambilan sampel dengan teknik total sampling (TFC) dan simple random sampling (NONTFC). Alat yang digunakan dalam penelitian ini adalah babyscale, dacin, babyboard dan microtoice. Uji kenormalan data menggunakan uji test Kolmogorov Smirnov dan analisis bivariat yang digunakan untuk mengetahui pengaruh antara variabel perubahan status gizi (BB/U dan TB/U) pada balita gizi kurang menggunakan uji statistik Simple T-Test Independent.

\section{HASIL PENELITIAN}

Penelitian tentang pengaruh TFC terhadap perubahan status gizi $(\mathrm{BB} / \mathrm{U}$ dan $\mathrm{TB} / \mathrm{U})$ pada balita gizi kurang di Kabupaten Sukoharjo. Jumlah balita yang mengikuti TFC sebanyak 50 balita tetapi hanya 35 balita yang masuk kriteria inklusi dan 15 balita di droup out karena 1 balita menderita sakit, 2 memiliki status gizi normal, 3 balita merupakan pergantian balita yang pernah hadir dan 9 balita pernah tidak hadir dalam pengambilan data. Responden balita yang tidak mengikuti TFC sejumlah 30 balita.

\subsection{ANALISIS UNIVARIAT}

\subsubsection{Jumlah Balita}

Tabel 1. Distribusi Subjek Berdasarkan Balita Mengikuti TFC dan Tidak Mengikuti TFC

\begin{tabular}{ccc}
\hline \multirow{2}{*}{ Subjek } & \multicolumn{2}{c}{ Jumlah } \\
\cline { 2 - 3 } & $\mathrm{n}$ & $\%$ \\
\hline TFC & 35 & 53,84 \\
NONTFC & 30 & 46,15 \\
\hline Jumlah & 65 & 100 \\
\hline
\end{tabular}

Berdasarkan tabel 1 distribusi balita yang mengikuti TFC lebih banyak yaitu 35 balita $(53,84 \%)$ dibandingkan dengan balita yang tidak mengikuti TFC sebanyak 30 balita $(46,15 \%)$.

\subsubsection{Jenis Kelamin}

Tabel 2. Distribusi Subjek

Berdasarkan Jenis Kelamin

\begin{tabular}{ccccccc}
\hline \multirow{2}{*}{ JK } & \multicolumn{2}{c}{ TFC } & \multicolumn{2}{c}{ NONTFC } & \multicolumn{2}{c}{ Jumlah } \\
\cline { 2 - 7 } & $\mathrm{n}$ & $\%$ & $\mathrm{n}$ & $\%$ & $\mathrm{n}$ & $\%$ \\
\hline $\mathrm{L}$ & 15 & 42,9 & 19 & 63,3 & 34 & 52,3 \\
$\mathrm{P}$ & 20 & 57,1 & 11 & 36,7 & 31 & 47,7 \\
$\mathrm{Jml}$ & 35 & 100 & 30 & 100 & 65 & 100 \\
\hline
\end{tabular}

Berdasarkan tabel 2 distribusi jenis kelamin yang mengikuti TFC lebih banyak perempuan sebesar 20 balita $(57,1 \%)$ dibandingkan laki-laki hanya 15 balita $(42,9 \%)$. Balita yang tidak mengikuti TFC lebih banyak berjenis kelamin laki-laki sebesar 19 balita $(53,3 \%)$ dibanding perem-puan 11 balita $(36,7 \%)$. Secara keseluruhan jenis kelamin yang mengalami gizi kirang lebih banyak laki-laki sebanyak 34 balita $(52,3 \%)$ dibandingkan dengan perempuan dengan jumlah 31 balita $(47,7 \%)$.

\subsubsection{Umur Balita}

Tabel 3. Distribusi Subjek Berdasarkan Umur Balita

\begin{tabular}{lcccccc}
\hline \multirow{2}{*}{$\begin{array}{l}\text { Umur } \\
\text { Bulan) }\end{array}$} & \multicolumn{2}{c}{ TFC } & \multicolumn{2}{c}{ NONT } & \multicolumn{2}{c}{ Jumlah } \\
\cline { 2 - 7 } & $\mathrm{n}$ & $\%$ & $\mathrm{n}$ & $\%$ & $\mathrm{n}$ & $\%$ \\
\hline $0-12$ & 3 & 8,6 & 3 & 10 & 6 & 9,3 \\
$13-24$ & 21 & 60 & 9 & 30 & 30 & 46,1 \\
$25-36$ & 6 & 17,1 & 8 & 26,7 & 14 & 21,6 \\
$37-48$ & 5 & 14,3 & 5 & 16,7 & 10 & 15,3 \\
$49-60$ & 0 & 0 & 5 & 16,7 & 5 & 7,7 \\
Jml & 35 & 100 & 30 & 100 & 65 & 100 \\
\hline
\end{tabular}

Berdasarkan tabel 3 distribusi umur balita gizi kurang yang mengikuti TFC dan tidak menikuti TFC paling banyak berusia antara 13 bulan hingga 24 bulan. Balita yang mengikuti TFC sebanyak 21 balita $(60 \%)$ dan yang tidak mengikuti TFC sejumlah 9 balita (30 \%). Keseluruhan balita paling banyak berusia $13-24$ bulan dengan jumlah 30 balita $(46,1 \%)$.

\subsubsection{Perkembangan Status Gizi BB/U Balita}

Gambaran status gizi perkembangan status gizi $\mathrm{BB} / \mathrm{U}$ pada balita yang mengikuti TFC dapat dilihat pada gambar 1. 
PROFESI (Profesional Islam)

Media Publikasi Penelitian; 2017; Volume 15; No 1.

Website: ejournal.stikespku.ac.id

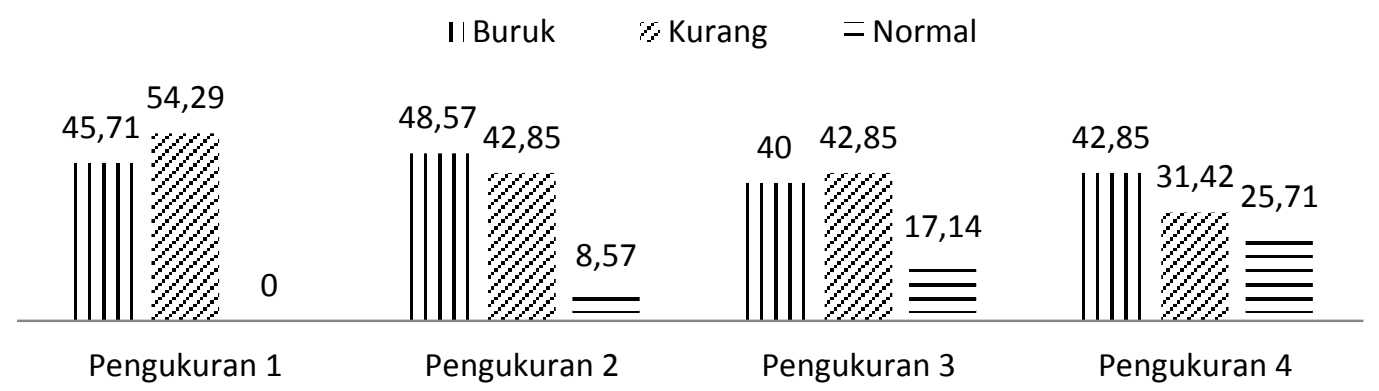

Gambar 1. Perkembangan Status Gizi BB/U Yang mengikuti TFC

Berdasarkan gambar 1 perkembangan status gizi $\mathrm{BB} / \mathrm{U}$ pada balita yang mengikuti TFC selama 90 hari mengalami perkembangan yang baik. Hal ini dapat dibuktikan bahwa selama pengukuran sebanyak 4 kali dalam 90 hari diketahui kasus gizi buruk dari awal hingga akhir mengalami penurunan yaitu dari 16 balita $(45,7 \%)$ menjadi 15 balita $(54,3 \%)$. Kasus gizi kurang mengalami penurunan dari awal hingga akhir yaitu dengan awal 19 balita (54,3\%) menjadi 11 balita $(31,4 \%)$. Selain itu, kasus gizi baik meningkat dari setiap pengukuran sampai akhir hingga akhir mancapai 9 balita $(25,7 \%)$.

Gambaran status gizi BB/U akhir balita yang mengikuti TFC dan tidak mengikuti TFC pada gambar 2 .

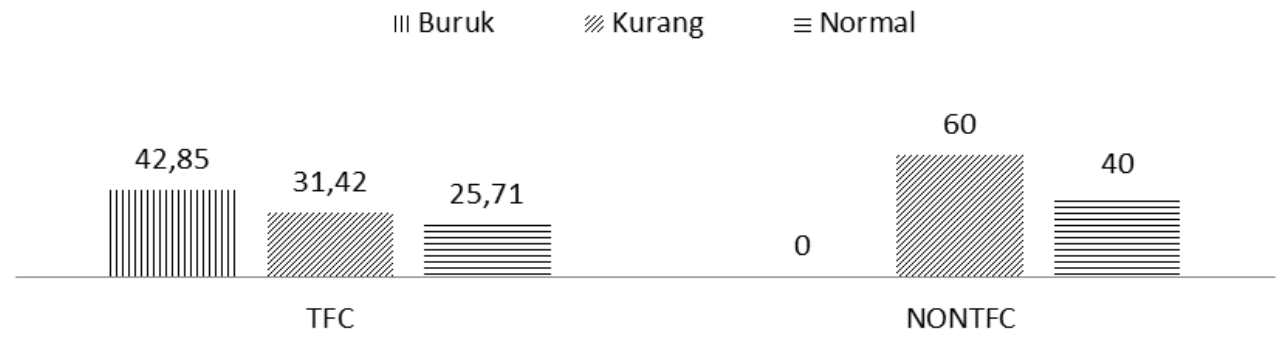

Gambar 2. Status Gizi BB/U Akhir Balita Gizi Kurang

Berdasarkan gambar 2 tentang status gizi $\mathrm{BB} / \mathrm{U}$ akhir balita gizi kurang yang mengikuti TFC dan tidak mengetahui TFC dapat diketahui bahwa hasilnya lebih baik pada yang tidak mengikuti TFC. Hal ini dapat dibuktikan dengan kasus pada yang mengikuti TFC status gizi buruk masih tergolong tinggi yaitu mencapai 15 balita $(42,9)$ dibandingkan yang tidak mengikuti TFC 0 balita (0\%). Gizi baik lebih tinggi pada balita yang tidak mengikuti TFC sebanyak 11 balita $(36,7 \%)$ dibandingkan dengan balita yang mengikuti TFC 9 balita $(25,7 \%)$.

\subsubsection{Perkembangan Status Gizi TB/U Balita}

Gambaran status gizi perkembangan status gizi $\mathrm{TB} / \mathrm{U}$ pada balita yang mengikuti TFC dapat dilihat pada gambar 3 .

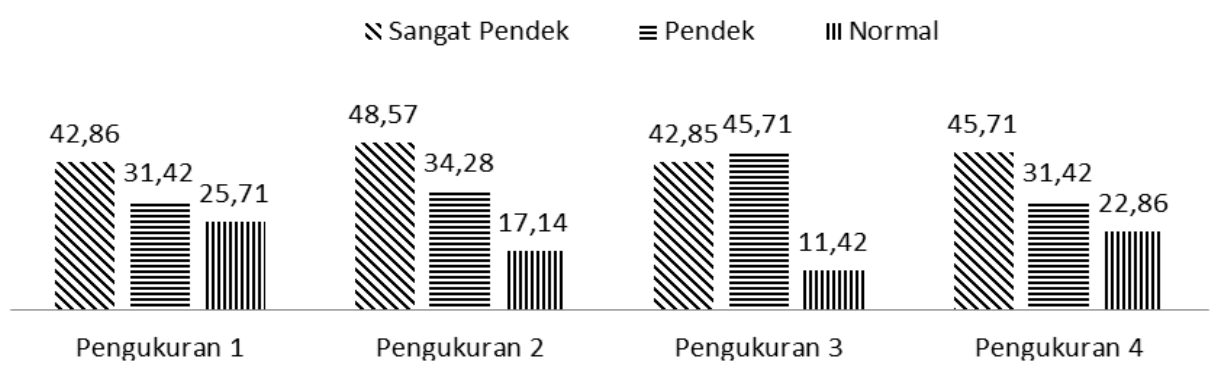

Gambar 3. Perkembangan Status Gizi TB/U Yang mengikuti TFC 
PROFESI (Profesional Islam)

Media Publikasi Penelitian; 2017; Volume 15; No 1.

Website: ejournal@stikespku.ac.id

Berdasarkan gambar 3 hasil penelitian menunjukkan bahwa status gizi balita dengan menggunakan indeks TB/U mempunyai hasil yang tidak signifikan. Status gizi sangat pendek, pendek dan normal tidak mengalami peningkatan menjadi lebih baik tetapi mengalami penurunan prosentasenya atau jumlahnya. Status gizi sangat pendek mengalami peningkatan mencapai 17 balita $(48,6 \%)$, pendek mencapai 11 balita $(31,4 \%)$ dan normal mengalami penurunan dari 9 balita $(25,7 \%)$ menjadi 7 balita $(20 \%)$.

Gambaran status gizi TB/U akhir balita yang mengikuti TFC dan tidak mengikuti TFC pada balita gizi kurang dapat dilihat pada gambar 4 .

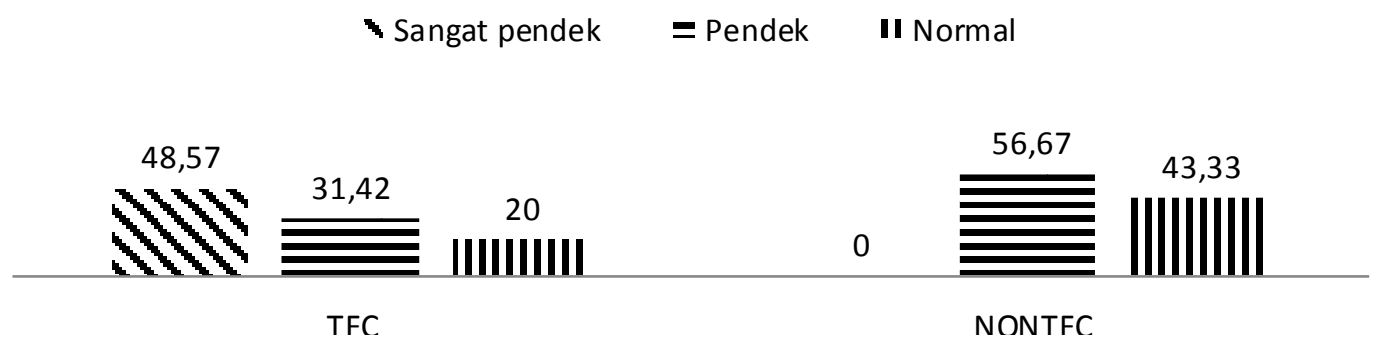

Gambar 4. Status Gizi TB/U Akhir Balita Gizi Kurang

Berdasarkan gambar 4 dapat diketahui bahwa hasil akhir lebih baik pada yang tidak mengikuti TFC. Hasil menyebutkan bahwa balita yang mengikuti TFC kasus sangat pendek pada balita masih tinggi yaitu mencapai 17 balita $(48,6 \%)$, pendek mencapai 11 balita $(31,4 \%)$ dan normal sebanyak 7 balita (20\%). Balita yang tidak mengikuti TFC tidak ada yang megalami kasus sangat pendek, pendek mencapai 17 balita $(56,7 \%)$ dan normal mencapai 13 balita $(43,3 \%)$.
Status gizi awal balita diambil pada pertemuan pertama dan sebagai penentu untuk status gizi keikutsertaan balita termasuk progam TF atau tidak. Status gizi akhir balita diperoleh pada pertemuan ke-12 dimana pertemuan ini merupakan pertemuan terkahir dari progam TFC. Pertemuan ini untuk mengetahui seberapa jauh progam berlangsung dan hasil akhir dapat mencapai target status gizi balita yang lebih optimal atau tidak. Status gizi awal dan akhir balita dapat dilihat pada tabel 4 berikut ini.

Tabel 4. Status Gizi Awal dan Akhir Subjek

\begin{tabular}{llcccc}
\hline \multirow{2}{*}{ Nilai } & \multicolumn{2}{c}{ TFC $(z$-score $)$} & \multicolumn{2}{c}{ NONTFC $(z$-score $)$} \\
\cline { 2 - 6 } & & BB/U & TB/U & BB/U & TB/U \\
\hline \multirow{4}{*}{ Awal } & Rata-rata & $-3,03$ & $-2,72$ & $-2,50$ & $-1,89$ \\
& Max & $-2,09$ & $-0,09$ & $-2,03$ & 0,39 \\
& Min & $-4,53$ & $-5,86$ & $-2,97$ & $-2,97$ \\
& SD & 0,70 & 1,08 & 0,31 & 1,00 \\
\hline \multirow{6}{*}{ Akhir } & Rata-rata & $-2,69$ & $-2,79$ & 2,02 & $-1,64$ \\
& Max & $-1,53$ & $-0,77$ & $-0,88$ & 1,40 \\
& Min & $-4,30$ & $-5,06$ & $-2,90$ & $-2,92$ \\
& SD & 0,80 & 0,95 & 0,48 & 1,13 \\
\hline
\end{tabular}

Berdasarkan tabel 4 dapat diketahui bahwa nilai rata-rata $z$-score awal yang mengikuti TFC dengan indeks $\mathrm{BB} / \mathrm{U}$ yaitu $-3,03 \pm 0,70$ dan $\mathrm{TB} / \mathrm{U}$ yaitu $-2,72 \pm 1,08$. Nilai akhir $z$-score dapat diketahui bahwa dengan indeks BB/U yaitu $2,69 \pm 0,80$ sedangkan yang $\mathrm{TB} / \mathrm{U}$ adalah $2,79 \pm 0,95$. Balita yang tidak mengikuti TFC mempunyai nilai rata-rata $z$-score awal dengan 
PROFESI (Profesional Islam)

Media Publikasi Penelitian; 2017; Volume 15; No 1.

Website: ejournal.stikespku.ac.id

indeks BB/U yaitu $-2,50 \pm 2,02$ dan TB/U adalah $1,89 \pm 1,00$. Nilai $z$-score akhir dengan indeks

BB/U yaitu 2,02 $\pm 0,48$ sedangkan $\mathrm{TB} / \mathrm{U}$ adalah $1,64 \pm 1,13$.

\subsection{ANALISIS BIVARIAT}

Tabel 5. Pengaruh TFC terhadap Perubahan Status Gizi BB/U dan TB/U Balita Gizi Kurang

\begin{tabular}{ccccccc}
\hline \multicolumn{2}{c}{ Perubahan Status Gizi } & Rata-rata & Min & Max & SD & p value \\
\hline \multirow{2}{*}{ BB/U } & TFC & 0,33 & $-1,08$ & 1,35 & 0,45 & \multirow{2}{*}{$0,34^{*}$} \\
& NONTFC & 0,44 & $-0,30$ & 1,44 & 0,45 & \\
\multirow{2}{*}{ TB/U } & TFC & $-0,06$ & $-0,83$ & 0,80 & 0,34 & \multirow{2}{*}{$0,26^{*}$} \\
& NONTFC & 0,25 & $-0,95$ & 2,26 & 0,61 & \\
\hline
\end{tabular}

*) : Uji statistik menggunakan $t$-test independent

Berdasarkan tabel 5 dapat diketahui bahwa rata-rata perubahan $z$-score indeks $\mathrm{BB} / \mathrm{U}$ yang mengikuti TFC adalah $0,33 \pm 0,45$ dan yang tidak mengikuti TFC yaitu $0,44 \pm 0,45$. Jadi dari hasil $t$ test menyimpulkan bahwa tidak ada pengaruh TFC terhadap perubahan status gizi BB/U pada balita gizi kurang yang mengikuti TFC dan tidak mengikuti TFC $(p \geq 0,05)$. Artinya tidak ada pengaruh yang signifikan pada perubahan status gizi $\mathrm{BB} / \mathrm{U}$ pada balita gizi kurang yang mengikuti TFC dan tidak mengikuti TFC ( $\mathrm{p}=0,34)$.

Berdasarkan tabel 5 dapat diketahui bahwa rata-rata perubahan $z$-score $\mathrm{TB} / \mathrm{U}$ yang mengikuti TFC adalah $-0,06 \pm 0,34$ dan yang tidak mengikuti TFC yaitu $0,25 \pm 0,61$. Jadi dari hasil t-test mengatakan bahwa tidak ada pengaruh TFC terhadap perubahan status gizi $\mathrm{TB} / \mathrm{U}$ pada balita gizi kurang yang megikuti TFC dan tidak mengikuti TFC $(p \geq 0,05)$. Artinya tidak ada pengaruh yang signifikan pada perubahan status gizi TB/U balita gizi kurang yang mengikuti TFC dan tidak mengikuti $\operatorname{TFC}(\mathrm{p}=0,26)$.

\section{PEMBAHASAN}

\subsection{Karakteristik Responden}

WHO (1999) dan Kemenkes (2011) menyebutkan bahwa penanganan anak gizi buruk terutama yang memiliki komplikasi medis dianjurkan melalui progam therapeutic feeding centre. TFC dapat dilakukan secara rawat inap di rumah sakit untuk balita yang mempunyai penyakit maupun rawat jalan untuk anak gizi buruk tanpa komplikasi dapat dilakukan perawatan jalan (tidak menginap di rumah sakit atau TFC). Kabupaten Sukoharjo memiliki sistem yang rawat jalan sehingga balita yang mengikuti TFC akan dipantau perkembangan status gizi oleh tim kesehatan selama 90 hari dengan sistem rawat jalan dan diberikan paket modisco (susu, gula dan minyak) yang berguna sebagai makanan tambahan balita untuk meningkatkan status gizi balita lebih optimal.

Berdasarkan hasil penelitian pada tabel 1 menunjukkan bahwa balita yang mengikuti TFC sebanyak 35 balita $(53,84 \%)$ sedangkan balita yang tidak mengikuti TFC sebanyak 30 balita $(46,15 \%)$. Hal ini menunjukkan balita yang mengikuti TFC maka akan dipantau selama 90 hari untuk mendapatkan paket modisco (susu, gula dan minyak) dengan sistem pemantauan setiap satu minggu sekali. Paket ini berupa paket makanan tambahan bagi balita yang dapat di minum atau makan sehari sebanyak 3 sampai 5 kali. Balita yang tidak mengikuti TFC tidak mendapatkan paket makanan tambahan tetapi dilakukan pemantauan selama 90 hari.

Berdasarkan tabel 2 dapat diketahui bahwa jenis kelamin yang mengikuti TFC lebih banyak perempuan sebesar 20 balita $(57,1 \%)$ dibandingkan laki-laki hanya 15 balita (42,9\%). Balita yang tidak mengikuti TFC lebih banyak berjenis kelamin laki-laki sebesar 19 balita $(53,3 \%)$ dibanding perempuan 11 balita (36,7\%). Secara keseluruhan jenis kelamin yang mengalami gizi kirang lebih banyak laki-laki sebanyak 34 balita $(52,3 \%)$ dibandingkan dengan perempuan dengan jumlah 31 balita $(47,7 \%)$. 
PROFESI (Profesional Islam)

Media Publikasi Penelitian; 2017; Volume 15; No 1.

Website: ejournal@stikespku.ac.id

Jenis kelamin berkaitan dengan kebutuhan energi yang pada umumnya laki-laki memiliki berat dan panjang badan lebih tinggi dibandingkan dengan perempuan yang menyebabkan lakilaki memiliki kebutuhan energi dan protein yang lebih tinggi dan lebih beresiko untuk terkena gizi buruk dibandingkan perempuan (Gaboulaud, 2007).

Berdasarkan tabel 3 umur balita gizi kurang yang mengikuti TFC dan tidak menikuti TFC paling banyak berusia antara 13 bulan hingga 24 bulan. Balita yang mengikuti TFC sebanyak 21 balita $(60 \%)$ dan yang tidak mengikuti TFC sejumlah 9 balita (30 balita). Keseluruhan balita paling banyak berusia $13-24$ bulan dengan jumlah 30 balita $(46,1 \%)$.

Hal ini disebabkan karena pada usia tersebut balita merupakan masa peralihan dari ASI ke makanan tambahan atau pada pada masa ini seharusnya masih diberi ASI tetapi tidak diberikan ASI dan juga makanan yang diberikan kurang, sehingga anak mengalami gizi buruk padahal masa ini bayi membutuhkan banyak energi untuk proses tumbuh kembangnya (Nahak., dkk, 2012).

Status gizi awal dalam penentuan keikutsertaan progam TFC yaitu balita dengan status gizi kurang atau buruk. Berdasarkan hasil penelitian balita yang mengikuti TFC berjumlah 35 balita yang terdiri dari 18 balit gizi kurang $(51,14 \%)$ dan 17 balita gizi buruk $(48,6 \%)$. Balita yang tidak mengikuti TFC sebanyak 30 balita dengan semuanya berstatus gizi kurang (100\%).

Faktor yang menyebabkan terjadinya gizi buruk adalah makanan yang diberikan kepada anak tidak dapat memenuhi ke butuhan anak akan berbaai zat yang diperlukan dan penghasilan keluarga yang terbatas. Sehingga pada usia ini apabila orang tua pengasuh anak tersebut tidak mengetahui kandungan zat gizi dalam makanan, makanan apa yang seharusnya diberikan dan penghasilan orang tua yang sangat minimum, akibatnya anak bisa mengalami gizi kurang dalam jangka waktu panjang sehingga menyebabkan anak terkena gizi buruk (Moehji, 2009).

Pengukuran yang telah dilakukan sebanyak 4 kali dapat memberikan proges status gizi balita yang dapat dilihat pada gambar 1. Berdasarkan gambar 1 perkembangan status gizi $\mathrm{BB} / \mathrm{U}$ pada balita yang mengikuti TFC selama 90 hari mengalami perkembangan yang baik. Hal ini dapat dibuktikan bahwa selama pengukuran sebanyak 4 kali dalam 90 hari diketahui kasus gizi buruk dari awal hingga akhir mengalami penurunan yaitu dari 16 balita $(45,7 \%)$ menjadi 15 balita (54,3\%). Kasus gizi kurang mengalami penurunan dari awal hingga akhir yaitu dengan awal 19 balita $(54,3 \%)$ menjadi 11 balita $(31,4 \%)$. Selain itu, kasus gizi baik meningkat dari setiap pengukuran sampai akhir hingga akhir mancapai 9 balita $(25,7 \%)$. Perkembangan peningkatan berat badan dan status gizi balita dapat terjadi karena adanya kerjasama yang baik antara keluarga, kader dan tenaga kesehatan selama pelaksanaaan merupakan kunci keberhasilan dalam kegiatan yang telah menjadi tujuan suatu progam (Muwarti dan Devianti, 2014).

Berdasarkan gambar 2 tentang status gizi $\mathrm{BB} / \mathrm{U}$ akhir balita gizi kurang yang mengikuti TFC dan tidak mengetahui TFC dapat diketahui bahwa hasilnya lebih baik pada yang tidak mengikuti TFC. Hal ini dapat dibuktikan dengan kasus pada yang mengikuti TFC status gizi buruk masih tergolong tinggi yaitu mencapai 15 balita $(42,9)$ dibandingkan yang tidak mengikuti TFC 0 balita $(0 \%)$. Gizi baik lebih tinggi pada balita yang tidak mengikuti TFC sebanyak 11 balita $(36,7 \%)$ dibandingkan dengan balita yang mengikuti TFC 9 balita $(25,7 \%)$.

Status gizi awal dengan mengguankan indeks TB/U dapat diketahui status gizi normal paling banyak pada balita yang tidak mengikuti TFC sebanyak 12 balita (40\%), status gizi pendek paling banyak juga pada balita yang tidak mengikuti TFC sebanyak 18 balita (60\%), sedangkan status gizi sangat pendek paling banyak pada balita yang mengikuti TFC sebanyak 17 balita $(48,7 \%)$.

Berdasarkan gambar 4 dapat diketahui bahwa hasil akhir lebih baik pada yang tidak mengikuti TFC. Hasil menyebutkan bahwa balita yang mengikuti TFC kasus sangat pendek pada balita masih tinggi yaitu mencapai 17 balita $(48,6 \%)$, pendek mencapai 11 balita $(31,4 \%)$ dan normal sebanyak 7 balita (20\%). Balita yang tidak mengikuti TFC tidak ada yang megalami kasus sangat pendek, pendek mencapai 17 balita $(56,7 \%)$ dan normal mencapai 13 balita $(43,3 \%)$. 


\subsection{Pengaruh TFC terhadap perubahan status gizi $(\mathrm{BB} / \mathrm{U}$ dan $\mathrm{TB} / \mathrm{U})$ pada balita gizi kurang}

Hasil penelitian menyimpulkan bahwa ratarata perubahan z-score indeks $\mathrm{BB} / \mathrm{U}$ yang mengikuti TFC adalah $0,33 \pm 0,45$ dan yang tidak mengikuti TFC yaitu $0,44 \pm 0,45$. Jadi dari hasil $t$ test menyebutkan bahwa tidak ada pengaruh TFC terhadap perubahan status gizi $\mathrm{BB} / \mathrm{U}$ pada balita gizi kurang yang mengikuti TFC dan tidak mengikuti TFC $(p \geq 0,05)$. Artinya tidak ada pengaruh yang signifikan pada perubahan status gizi $\mathrm{BB} / \mathrm{U}$ pada balita gizi kurang yang mengikuti TFC dan tidak mengikuti TFC $(p=0,34)$. Hasil penelitian ini menunjukkan bahwa tidak ada pengaruh TFC terhadap perubahan status gizi $(\mathrm{BB} / \mathrm{U})$ pada balita gizi kurang Hasil akhir menyimpulkan tidak ada pengaruh, tetapi dari data penelitian dapat diketahui perkembangan status gizi balita mengalami peningkatan. Hal ini dapat dilihat pada gambar 1 yang menggambarkan bahwa status gizi baik balita mengalami perkembangan yang signifikan pada pengukuran ke-1 hingga pengukuran yang terakhir yaitu ke-4. Peningkatan perkembangan status gizi balita bisa disebabkan karena penambahan berat badan. Tetapi hasil penambahan berat badan belum maksimal sehingga belum dapat memperbaiki status gizi lebih optimal.

Hasil penelitian juga menyimpulkan bahwa rata-rata perubahan $z$-score $\mathrm{TB} / \mathrm{U}$ yang mengikuti TFC adalah $-0,06 \pm 0,34$ dan yang tidak mengikuti TFC yaitu $0,25 \pm 0,61$. Jadi dari hasil t-test mengatakan bahwa tidak ada pengaruh TFC terhadap perubahan status gizi TB/U pada balita gizi kurang yang megikuti TFC dan tidak mengikuti TFC $(p \geq 0,05)$. Artinya tidak ada pengaruh yang signifikan pada perubahan status gizi TB/U balita gizi kurang yang mengikuti TFC dan tidak mengikuti $\operatorname{TFC}(\mathrm{p}=0,26)$. Meskipun hasil akhir menyimpulkan tidak ada pengaruh, dari data penelitian dapat diketahui bahwa terdapat perkembangan perubahan status gizi TB/U pada balita yang mengikuti TFC pada gambar 3. Pertumbuhan tinggi badan tidak seperti berat badan, relatif lebih kurang sensitif terhadap masalah kekurangan gizi dalam waktu yang pendek. Pengaruh defisiensi gizi terhadap tinggi badan akan nampak dalam waktu yang relatif lama. Sehingga dengan waktu 90 hari belum dapat memaksimalkan perkembangan status gizi TB/U pada balita.

Hasil penelitian yang sama ditunjukkan oleh penelitian Abdi dkk (2011) yang meneliti tentang pengaruh pemberian makanan tambahan (PMT) pada anak balita BGM melalui metode kelompok gizi terhadap peningkatan status gizi balita. Hasil penelitian menunjukkan bahwa tidak ada perbedaan status gizi yang signifikan antara anak balita yang diberi PMT dengan metode Kelompok Gizi (perlakuan) dengan yang Kontrol. Hal ini karena kedua kelompok tidak menunjukkan adanya perubahan status gizi ke arah yang lebih baik secara signifikan walaupun sudah diberikan intervensi berupa PMT selama 30 hari. Asupan zat gizi (energi) yang masih defisit menjadi salah satu penyebab utama tidak bertambahnya berat badan anak balita secara optimal. Berdasarkan hasil pengamatan pada saat penelitiannya, ibu anak balita sering memberikan makanan ringan kepada anak balitanya sebelum diberikan PMT sehingga anak menjadi kenyang dan konsumsi makanan utama menjadi tidak maksimal. Selain itu, beberapa ibu anak balita menganggap bahwa pemberian PMT dapat mengganti salah satu waktu makan utama anak balita (misalnya: makan siang atau makan malam) akibatnya ibu tidak memberikan makan lagi pada anak balitanya di salah satu waktu makan tersebut.

Hasil keseluruhan pada penelitian ini menyimpulkan bahwa tidak ada pengaruh TFC terhadap perubahan status gizi $(\mathrm{BB} / \mathrm{U}$ dan $\mathrm{TB} / \mathrm{U})$ pada balita gizi kurang. Berdasarkan hasil penelitian disebabkan karena antara balita yang mengikuti TFC dan tidak mengikuti TFC tidak menunjukkan adanya peningkatan berat badan secara signifikan. Sesuai dengan hasil pengamatan dan wawancara yang telah dilakukan bahwa tidak terjadinya peningkatan karena ibu kurang telaten saat memberikan paket modisco yang telah diberikan, misalnya ketika balita sudah bosan dengan paket yang hanya dibuat dengan susu, ibu tidak berusaha untuk memodifikasikan paket menjadi makanan yang lain seperti yang sudah diajarkan saat penyuluhan. Ibu membagi dengan anggota keluarga lainnya, sehingga asupan yang seharusnya masuk kedalam balita terbagi menjadi dua yaitu anggota yang lain dan balita tersebut. Selain itu, beberapa ibu anak balita menganggap bahwa pemberian 
PROFESI (Profesional Islam)

Media Publikasi Penelitian; 2017; Volume 15; No 1.

Website: ejournal@stikespku.ac.id

paket modisco dapat mengganti salah satu waktu makan utama anak balita (misalnya: makan siang atau makan malam) akibatnya ibu tidak memberikan makan lagi pada anak balitanya di salah satu waktu makan tersebut.

Progam TFC yang berlangsung selama 12 minggu mempunyai kendala yang hampir 3 Puskesmas mengalaminya. Kendala tersebut yaitu mengenai kepatuhan dalam mengkonsumsi modisco. Petugas kesehatan tidak melakukan pengawasan atau pemantaun kepada keluarga secara rutin sehingga tidak dapat diketahui modisco diberikan atau diminum secara baik oleh balita. Kendala yang lain yaitu dalam pembuatan modisco banyak ibu-ibu yang tidak ingat cara pembuatan maupun resepnya, kepatuhan untuk mengonsumsi modisco setiap hari dengan ratarata 3-5x dalam satu hari yang jarang dilakukan oleh keluarga, banyak keluarga berfikir bahwa paket modisco merupakan salah satu pengganti dari makanan utama (makan siang atau malam) dan keluarga membagi modisco dengan anggota keluarga yang lain. Pemantauan kepatuhan mengkonsumsi modisco sangat diperlukan untuk dapat mengetahui keberhasilan progam. Petugas dapat mendampingi secara langsung, melakukan kunjungan rumah ataupun wawancara saat pengambilan paket modisco pada setiap minggunya. Kepatuhan yang baik dan teratur dapat meningkatkan konsumsi modisco.

Merurut Asworth (2006) balita membutuhkan kebutuhan asupan yang tinggi untuk meningkatkan status gizi menjadi lebih optimal. Kebutuhan asupan pada balita yaitu tinggi energi mencapai $>150 \mathrm{kkal} / \mathrm{kg} / \mathrm{hari}$ dan tinggi protein yaitu 4-6 gr/ $/ \mathrm{kg} / \mathrm{hari}$ serta zat gizi mikronutrien yang lain. Asworth meneliti tentang keefektifan beberapa progam tentang penanggulangan kasus gizi buruk pada balita. Progam perawatan dirumah dengan pemberian penyediaan susu, gula dan minyak tidak efektif di Trinidad dan Jamaika. Ketidakefektifan ini bisa disebabkan karena makanan tidak mengandung energi padat (terlalu banyak air), makanan terlalu sedikit karena harus dibagi dengan anggota keluarga lainnya, paket yang diberikan merupakan makanan tambahan tetapi banyak yang berfikir bahwa paket digunakan untuk menganti makanan pokok (makan siang atau malam), kebiasaan makan anggota keluarga dapat mempengaruhi kebiasaan makan balita, ibu tidak mempunyai waktu atau tenaga atau bahan untuk menyediakan kepada anak secara rutin, infeksi yang berulang karena keluarga hidup pada lingkungan yang kumuh sehingga dapat terkena infeksi, makanan suplemen diganti dengan makanan lain yang kandungan energinya tidak sama, anggota keluarga lain kurang mendukung, pesan-pesan yang diberikan tidak diingat, keluarga terlalu miskin untuk mengimplementasikan saran-saran dan kehadiran yang tidak rutin atau jarang yang disebabkan karena faktor jarak yang terlalu jauhm kesempatan dan juga biaya.

\section{SIMPULAN}

Tidak ada pengaruh Therapeutic Feeding Centre terhadap perubahan status gizi $(\mathrm{BB} / \mathrm{U}$ dan $\mathrm{TB} / \mathrm{U}$ ) pada balita gizi kurang di Kabupaten Sukoharjo.

\section{SARAN}

1. Sasaran yang diberikan untuk progam penanggulangan masalah balita harus sesuai dengan status gizi awal yaitu gizi kurang

2. Untuk meningkatkan efisiensi paket modisco, perlu dilaksanan proses pendampingan secara kontinu, agar jumlah kandungan gizi dalam paket dapat diserap secara terpenuhi sesuai dengan rencana progam yang diberikan pada balita gizi kurang dan buruk.

3. Petugas kesehatan melakukan pemantauan kepatuhan mengkonsumsi modisco yang dapat meningkatkan konsumsi modisco oleh balita.

\section{KETERBATASAN PENELITIAN}

Tidak dilakukan monitoring evaluasi dalam pelaksanaan progam TFC khususnya pada kepatuhan mengkonsumsi modisco yang telah diberikan.

\section{REFERENSI}

Ashworth, A. 2006. Efficacy and effectiveness of community based treatment of severe malnutrition. Food and Nutrition Bulletin, vol. 27, no. 3 (supplement), The United Nations University

Abdi, L., Sulendri, N. K. S., Adiyasa, I., Taufiqurrahman. 2011. Pengaruh Pemberian Makanan Tambahan (PMT) Pada Anak BGM Melalui Metode Kelompok 
Gizi Terhadap Peningkatan Statuz Gizi Anak Balita Di Kecamatan Gunungsari. Jurnal Kesehatan Prima Vol 5 No 2. Jurusan Gizi Poltekes Kemenkes Mataram. Mataram

Dinas Kesehatan Kabupaten Sukoharjo. 2015. Prevalensi Status Gizi Balita Menurut Indeks BB/U Tahun 2015. Dinas Kesehatan Kabupaten Sukoharjo

Dinas Kesehatan Kabupaten Sukoharjo. 2016. Prevalensi Status Gizi balita Menurut Indeks BB/U Tahun 2016. Dinas Kesehatan Kabupaten Sukoharjo

Feinstorm, J D., Uauy, R \& Arroyo, P. 2005. Nutrition And Brain. Center For International Child health. Institute of child health/ univercity of London UK.

Gaboulaud, V. 2007. Could Nutritional Rehabilitation At Home Complement Or Replace Centre-Based Therapeutic Feeding Programmes For Severe Malnutrition. Journal of Tropical Pediatrics;53(1):49-51

Hickson, M. 2006. Malnutrition and Ageing. Nutrition and Dietetic Departement, Charing Cross Hospital, Fulham Palace Road, London. Postgrad Med J. 2006. $82: 2-8$

Kementerian Kesehatan. 2011. Buku Saku Penanggulangan Daerah Bermasalah Kesehatan. Kementerian Kesehatan Republik Indonesia. Jakarta.

Moehji, S. 2009. Ilmu Gizi Penanggulangan Gizi Buruk. Jakarta: Papas Sinar Sinanti

Muller, O and Krawinkel M. 2005. Malnutrition and Health Developing Countries. Canadian Medical Assosiation Journal, 173, 279-286
Murwati., dan Devianti, T. 2014. Peningkatan Status Gizi Balita Dengan Gizi Buruk Melalui Pemberian Formula 100. Kementerian Kesehatan Politeknik Kesehatan Surakarta Jurusan Kebidanan

Nahak, M D., Herawati dan Sulistyowati, Y. 2012. Pengaruh Pemberian Makanan Tambahan (PMT) Terhadap Perubahan Berat Badan Anak Gizi Buruk, Usia 6-60 Bulan Di Therapeutic Feeding Centre (TFC), Kecamatan Malaka Tengah Kabupaten Nusa Teggara Timur. Yogyakarta; Universitas Respati Yogyakarta, Jurusan Gizi Politeknik Kesehatan Yogyakarta, Ilmu Gizi Universitas Respati Yogyakarta. Yogyakarta

Riskesdas. 2013. Status Gizi Anak Berdasarkan Indikoator BB/U Pada Balita. Jakarta

Rosha, B C., Setyowati, B., Utami, N. 2014. Hubungan Lama Perawatan Dengan Status Gizi Setelah Perawatan Di Therapeutic Feeding Centre (TFC) Pada Anak Gizi Buruk Di Kabupaten Boalemo, Provinsi Gorontalo. Gorontalo. Peneliti Pusat Teknologi Intervensi Kesehatan Masyarakat. Gorontalo

Suhardjo. 2003. Berbagai Cara Pendidikan Gizi. Bogor: Bumi Aksara

Supariasa, I D N., Bakri, B dan Fajar, I. 2002. Penilaian Status Gizi. Jakarta: EGC

Supartini, Y. 2004. Buku Ajar Konsep dasar Keperawatan Anak. Jakarta: EGC

World Health Organization. (1999).

Management of severe malnutrition : a manual for physicians and other senior health workers. Geneva: World Health Organization. 